DOI: https://doi.org/10.15407/techned2019.05.077

\title{
IMPROVING THE EFFICIENCY OF HIGH-VOLTAGE ELECTRIC DISCHARGE INSTALLATIONS WHICH USE EXOTHERMAL DISPERSED MEDIA
}

\author{
Journal \\ Publisher \\ ISSN \\ Issue \\ Pages
}

\author{
Tekhnichna elektrodynamika \\ Institute of Electrodynamics National Academy of Science of Ukraine \\ 1607-7970 (print), 2218-1903 (online) \\ No 5, 2019 (September/Oktober) \\ $77-82$
}

\footnotetext{
Authors

Vovchenko O.I.*, Demydenko L. Yu. ${ }^{\star \star}$, Blashchenko O.D. ${ }^{\star \star \star}$, Starkov I.M. ${ }^{\star \star \star \star}$

Institute of Pulse Processes and Technologies National Academy of Sciences of Ukraine, Bohoiavlenskii Avenue, 43-A, Mykolaiv, 54018, Ukraine,

e-mail: dpte@iipt.com.ua ,iipt@iipt.com.ua

* ORCID ID : http://orcid.org/0000-0002-5837-2208

** ORCID ID : http://orcid.org/0000-0003-3045-0419

*** ORCID ID : http://orcid.org/0000-0002-1778-5065

**** ORCID ID : http://orcid.org/0000-0002-9740-3468
}

\begin{abstract}
The article shows that the use of high-voltage electrical discharge installations, instead of traditional single-circuit capacitive double-circuit pulse generators, as well as control of the energy accumulated in them (by changing the capacitances and / or voltages of their charge) and the moment of energy input into the interelectrode gap filled with exothermic dispersed medium, allows to increase more than 1.5 times the energy efficiency of such facilities. This approach is especially effective when using exothermic medium containing aluminum with different dispersity as a fuel. In this case, the increase in the energy characteristics of the electric-discharge installations is ensured by increasing the duration of the exothermic processes. Moreover, one of the most important conditions for increasing the energy characteristics of such facilities is to maintain the pressure in the channel above the critical
\end{abstract}


value ( 22.5 MPa), which is necessary for the flow of self-sustaining exothermic reactions. Ref erences 10 , figures 5 .

Key words: electric discharge, high-voltage installation, interelectrode gap, controlled introduction of energy, channel of discharge, exothermic medium, pressure, energy efficiency.

Received: 02.01.2019

Accepted: 11.06 .2019

Published: 01.08.2019

\section{References}

1. Vovchenko O.I., Posokhov A.A. Controlled electric explosion processes of energy conversion in condensed media. Kyiv: Naukova dumka, 1992. 168 p. (Rus.)

2. Rizun, A.R., Golen. Yu.V., Denisyuk T.D., Mushtatny G.P. Pulsed electric discharge technologies in construction. Budivnytstvo Ukrainy. 2008. No 10. Pp. 29 - 31. (Rus.)

3. Kornev la., Saprykin F., Lobanova G., Ushakov V., Preis S. Spark erosion in a metal spheres bed: Experimental study of the discharge stability and energy efficiency. Journal of Electrostatics 2018. Vol. 96. Pp. 111-118.

DOI:

https://doi.org/10.1016/j.elstat.2018.10.008

4. Gerasimov B.V., Pozdeev V.A. High-voltage electrochemical explosion in the discharge-pulse technology of fitting the tubes in tube sheets. Collection of scientific works of In-that pulse processes and technologies of the National Academy of Sciences of Ukraine. Physical and technical aspects of electric energy conversion. Kyiv. 1990. Pp. 85-89. (Rus.)

5. Shcherba A.A., Kosenkov V.M., Bychkov V.M. Mathematical closed model of electric and magnetic fields in the discharge chamber of an electrohydraulic installation. Surface

Engineering and Applied Electrochemistry

. 2015. Vol. 51. Issue 6. Pp 581-588.

DOI:

https://doi.org/10.3103/S1068375515060113

6. Tertilov R.V. Optimization of discharge-pulse technologies based on the use of dual-circuit pulse current generators. Tekhnichna Elektrodynamika. 2011. No 3. Pp. 67-72. (Rus.)

7. Kravchenko V.I., Petkov A.A. Parametrical synthesis of high-voltage pulse test device with capacitive energy storage. Elektrotehnika i elektromehanika. 2007. No 6. Pp. 70-75. (Rus.) 8. Suprunovska N.I., Shcherba A.A., Ivashchenko D.S., Beletsky O.A. Prosesses of energy 
exchange between nonlinear and linear links of electric equivalent circuit of supercapacitors. Te khnicna Elektrodynamika

, 2015. No 5. Pp. 3-11. (Rus.)

9. Vovchenko O.I., Demidenko L.Yu., Starkov I.M. The processes of energy conversion in high-voltage electrochemical explosion in limited quantities. Elektronnaia obrabotka materialov. 2017, No 53 (5). Pp. 41-47. (Rus.)

10. Vovchenko O.I., Demidenko L.Yu., Starkov I.M. Algorithms for calculating the parameters of the combined electric discharge source of energy in the high-voltage electrochemical explosion (hvee) in confined volumes. Elektronnaia obrabotka materialov. 2018. No 54 (3). Pp. 69-73.

(Rus.)

DOI: https://doi.org/10.31

$\underline{03 / S 1068375518050113}$

$\underline{\text { PDF }}$ 